\title{
Influence of the atrio-ventricular delay optimization on the intra left ventricular delay in cardiac resynchronization therapy Christoph Melzer*1, Fabian Knebel ${ }^{1}$, Bruno Ismer ${ }^{2}$, Hansjürgen Bondke ${ }^{2}$, Christoph A Nienaber ${ }^{2}$, Gert Baumann ${ }^{1}$ and Adrian C Borges ${ }^{1}$
}

Address: ${ }^{1}$ Universitätsmedizin Berlin, Medical Clinic for Cardiology, Angiology, Pulmology, Charité Campus Mitte, Germany and ${ }^{2}$ University of Rostock, Clinic for Internal Medicine, Rostock, Germany

Email: Christoph Melzer* - christoph.melzer@charite.de; Fabian Knebel - fabian.knebel@charite.de; Bruno Ismer - bruno.ismer@med.unirostock.de; Hansjürgen Bondke - hansjuergen.bondke@charite.de; Christoph A Nienaber - christoph.nienaber@med.uni-rostock.de; Gert Baumann - gert.baumann@charite.de; Adrian C Borges - adrian.borges@charite.de

* Corresponding author

Published: 26 January 2006

Cardiovascular Ultrasound 2006, 4:5 doi:10.1/86/1476-7/20-4-5
Received: 23 December 2005

Accepted: 26 January 2006

This article is available from: http://www.cardiovascularultrasound.com/content/4/1/5

(C) 2006 Melzer et al; licensee BioMed Central Ltd.

This is an Open Access article distributed under the terms of the Creative Commons Attribution License (http://creativecommons.org/licenses/by/2.0), which permits unrestricted use, distribution, and reproduction in any medium, provided the original work is properly cited.

\begin{abstract}
Background: Cardiac Resynchronization Therapy (CRT) leads to a reduction of left-ventricular dyssynchrony and an acute and sustained hemodynamic improvement in patients with chronic heart failure. Furthermore, an optimized AV-delay leads to an improved myocardial performance in pacemaker patients. The focus of this study is to investigate the acute effect of an optimized AVdelay on parameters of dyssynchrony in CRT patients.
\end{abstract}

Method: I I chronic heart failure patients with CRT who were on stable medication were included in this study. The optimal AV-delay was defined according to the method of Ismer (mitral inflow and trans-oesophageal lead). Dyssynchrony was assessed echocardiographically at three different settings: $A V D_{O P T} ; A V D_{O P T}-50 \mathrm{~ms}$ and $A V D_{O P T}+50 \mathrm{~ms}$. Echocardiographic assessment included 2Dand $\mathrm{M}$-mode echo for the assessment of volumes and hemodynamic parameters $(\mathrm{Cl}, \mathrm{SV})$ and LVEF and tissue Doppler echo (strain, strain rate, Tissue Synchronisation Imaging (TSI) and myocardial velocities in the basal segments)

Results: The $\mathrm{AVD}_{\mathrm{OPT}}$ in the VDD mode (atrially triggered) was $105.5 \pm 38.1 \mathrm{~ms}$ and the $\mathrm{AVD}_{\mathrm{OPT}}$ in the DDD mode (atrially paced) was $186.9 \pm 52.9 \mathrm{~ms}$. Intra-individually, the highest LVEF was measured at $A V D_{O P T}$. The LVEF at $A V D_{O P T}$ was significantly higher than in the $A V D_{O P T-50}$ setting ( $P$ $=0.03$ ). However, none of the parameters of dyssynchrony changed significantly in the three settings.

Conclusion: An optimized AV delay in CRT patients acutely leads to an improved systolic left ventricular ejection fraction without improving dyssynchrony.

\section{Background}

Asynchronous myocardial contraction in heart failure is associated with poor prognosis. Recent studies have shown an acute and sustained hemodynamic improve- ment after biventricular pacing (BVP), reversal of LVremodelling, an increased quality of life, a reduction of symptoms of heart failure, and an improvement of exercise tolerance [1-7]. 
Table I: Patient characteristics

\begin{tabular}{|c|c|}
\hline $\left.\mathrm{Age}_{(\text {mean }} \pm \mathrm{SD}\right)$ & $63.2 \pm 11.7$ \\
\hline Gender $(\mathrm{m} / \mathrm{f})_{(\mathrm{n} / \%)}$ & $7(63.6) / 4(36.4 \%)$ \\
\hline Coronary artery disease $(\mathrm{n} / \%)$ & $4(36.4 \%)$ \\
\hline Dilated Cardiomyopathy $(\mathrm{n} / \%)$ & $7(63.6 \%)$ \\
\hline Left-ventricular ejection fraction $($ mean \pm SD) & $27.3 \% \pm 11.9$ \\
\hline Interval in months between stress testing and ICD implantation (months) ${ }_{(\text {mean } \pm S D)}$ & $11.9 \pm 12.9$ \\
\hline \multicolumn{2}{|l|}{ location of the CS - electrode } \\
\hline lateral & $6(54 \%)$ \\
\hline posterolateral & $4(36.4 \%)$ \\
\hline anterolateral & I $(9 \%)$ \\
\hline diabetes mellitus (n/\%) & $6(54 \%)$ \\
\hline \multicolumn{2}{|l|}{ medication } \\
\hline ACE inhibitors $(n / \%)$ & $9(82 \%)$ \\
\hline $\operatorname{ARB}_{(n / \%)}$ & $2(18 \%)$ \\
\hline Beta-blockers (n/\%) & $10(91 \%)$ \\
\hline Digitalis $_{(\mathrm{n} / \%)}$ & $8(73 \%)$ \\
\hline Diuretics $_{(\mathrm{n} / \%)}$ & II (I00\%) \\
\hline spironolactone ${ }_{(\mathrm{n} / \%)}$ & $8(73 \%)$ \\
\hline
\end{tabular}

$A R B=$ Angiotensin-receptor blockers;

$\mathrm{CS}=$ coronary sinus

The optimization of the AV delay in DDD pacemaker patients is generally recommended and is performed in clinical practice. A variety of invasive and non-invasive methods were assessed in the past [8-15]. Recent studies have shown that also in CRT patients, invasively $(\mathrm{dP} / \mathrm{dt})$ [16-19] and non-invasively measured hemodynamic parameters (stroke volume) $[20,21]$ are modified according to the programmed AV delay. A hemodynamically optimal AV delay can be defined.

Ismer's method of AV delay optimization [22] is validated for biventricular as well as right ventricular DDD pacing.

Tissue Doppler Imaging (TDI) is an evaluated tool in clinical practice to identify myocardial dyssynchrony. TDI (including strain and strain rate) imaging measures regional wall motion velocities and can accurately quantify regional left ventricular function [24].
Strain measures compression and distension of myocardial segments ("deformation imaging") and strain rate imaging expresses strain changes per time interval [25]. TSI (Tissue Synchronization Imaging) utilizes color-coded time-to-peak tissue Doppler velocities and visualizes segments of dyssynchrony in real-time by superimposing these temporal motion data on 2D echo images. [26,27].

These new techniques could potentially improve patient selection and guidance of implantation and programming of the devices for BVP. There is a variety of methods to determine dyssynchrony as summarized elsewhere [28].

There are no published data on the correlation of parameters of dyssynchrony and programming of the optimal $\mathrm{AV}$ interval. Aims of our study were therefore to investigate the influence of an optimized AV delay determined by the method of Ismer et al. [22] on dyssynchrony.

Table 2: Measurement of the components of the optimal AV delay according to Ismer et al. [22]

\begin{tabular}{ll}
\hline pacemaker-related interatrial conduction interval (IACT) & $\begin{array}{l}\text { VDD pacing: MA-LA measured between right-atrial sense-event marker } \\
(\mathrm{MA}) \text { and the beginning of left-atrial deflection }(\mathrm{LA}) \text { in oesophageal } \\
\text { electrogram }\end{array}$ \\
$\begin{array}{l}\text { DDD pacing: SA-LA measured between right-atrial pacing stimulus }\left(\mathrm{S}_{\mathrm{A}}\right) \\
\text { and the beginning of left-atrial deflection }(\mathrm{LA}) \text { in oesophageal } \\
\text { electrogram }\end{array}$ \\
$\begin{array}{l}\text { Measured during unphysiologically long programmed } A V \text { delay between } \\
\text { the beginning of left-atrial deflection (LA) in oesophageal electrogram } \\
\text { and the end of the left-atrial contribution (EAC) in transmitral flow. }\end{array}$ \\
$\begin{array}{l}\text { Measured during unphysiologically short programmed } A V \text { delay between } \\
\text { ventricular pacing stimulus (Sv) and the end of the left-atrial contribution } \\
\text { left-ventricular electromechanical latency period (Sv-EAC }\end{array}$ \\
(EAC) in transmitral flow.
\end{tabular}




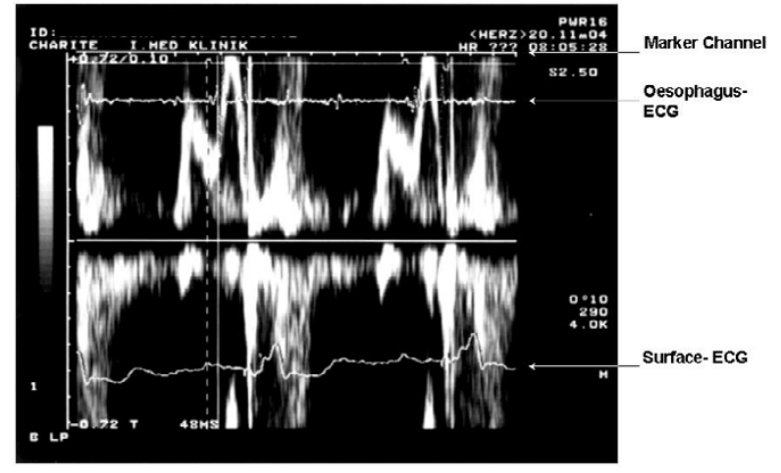

Figure I

Measurement of the IACT in the VDD - Mode = MA-LA. MA = right atrial sensing marker (see marker channel). $L A=$ left atrial deflection (see oesophageal ECG). In this particular patient the IACT is $48 \mathrm{~ms}$.

\section{Methods \\ Patients}

11 chronic heart failure patients of our clinic were included in this study. All patients had a biventricular ICD (pre-implantation NYHA III-IV, EF < 35\%, QRS width > $120 \mathrm{~ms}$ ). Clinical characteristics are demonstrated in Table 1. Patient exclusion criteria were as follows: atrial fibrillation, pacemaker malfunction and oesophageal diseases, NYHA IV, prosthetic mitral valve replacement.

\section{AV delay: components and optimization}

For the AV delay optimization we used the method proposed by Ismer et al [22].

This approach needs the placement of a bi-polar oesophageal electrode to provide a filtered left-atrial electrogram (LAE). We applied a 5F oesophagus electrode (Osypka TO2/5F, order no. TA12991101, Rheinfelden, Germany). Filtered oesophageal electrogram and telemetric real-time pacemaker markers provided by the programmer's analogue output were superimposed on the display of transmitral flow velocity on the Doppler-echo system (Figure 1 ). The simultaneous recording of transmitral flow, the left atrial oesophageal electrogram and the real-time sense-event markers, allow determining the components of the optimal AV delay (Table 2, Figure 1 and 2).

Based on these measurements, optimal AV delays were calculated for VDD (atrial-triggered) and DDD (atrialpaced) mode using the equations:

$\mathrm{AVD}_{\mathrm{OPT}} \mathrm{VDD}=\mathrm{MA}-\mathrm{LA}+\mathrm{LA}_{\mathrm{E}} \mathrm{EAC}_{\text {long }}-\mathrm{Sv}-\mathrm{EAC}_{\text {short }}$

and

$\mathrm{AVD}_{\mathrm{OPT}} \mathrm{DDD}=\mathrm{SA}-\mathrm{LA}+\mathrm{LA}_{\mathrm{E}} \mathrm{EAC}_{\text {long }}-\mathrm{Sv}^{-\mathrm{EAC}_{\text {short }}}$

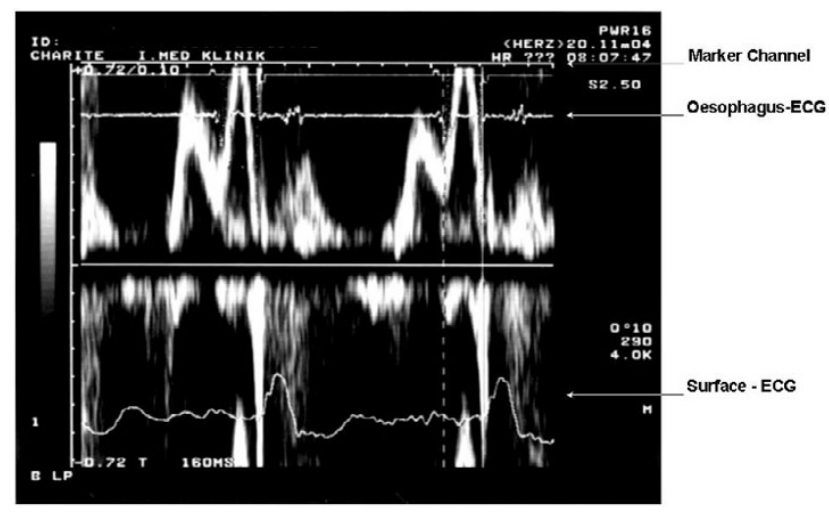

Figure 2

Assessment of the left-atrial electromechanical action = LA$\mathrm{EAC}_{\text {long. }}$. $\mathrm{AA}=$ left atrial deflection (see oesophagus- ECG). $E A C_{\text {long }}=$ the end of the $A$-wave in an unphysiologically long

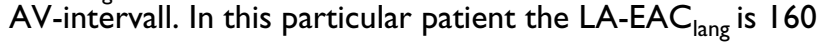
ms

\section{Echocardiograhy}

Echocardiography to assess dyssynchrony was performed subsequently under three pacemaker settings: optimal AV delay $\left(\mathrm{AVD}_{\mathrm{OPT}}\right)$, optimal $\mathrm{AV}$ delay minus $50 \mathrm{~ms}\left(\mathrm{AVD}_{\mathrm{OPT}^{-}}\right.$ $50)$, optimal AV delay plus $50 \mathrm{~ms}\left(\mathrm{AVD}_{\mathrm{OPT}^{+}}+50\right)$.

Echocardiography was performed on the Vivid 5 and Vivid 7 Dimension (GE Vingmed Ultrasound, Horton, Norway) machines. The TDI and strain analysis were performed in an off-line work station. The LVEF was assessed by area-length method in the apical four chamber view. The CI and the SV were calculated from the systolic velocities measured by PW-Doppler in the aortic outflow tract. Strain rate, tissue Doppler velocities were measured in the basal segments of the apical four-, three- and two-chamber views.

\section{Statistics}

Values are expressed as mean \pm standard deviation (SD). Groups were compared by parametric or non-parametric tests (t-tests and Wilcoxon-Mann-Whitney tests, respectively). Statistical significance was assumed at a value of $\mathrm{P}$ $<0.05$. Statistical analysis was performed with the SPSS 12 software package (SPSS; Chicago, Ill, USA).

\section{Results}

\section{Optimal AV delay}

In all patients, we could define an optimal AV delay in the VDD and the DDD modes respectively. The $\mathrm{AVD}_{\mathrm{OPT}}$ in VDD mode was $105.5 \pm 38.1 \mathrm{~ms}$ and the $\mathrm{AVD}_{\mathrm{OPT}}$ in the DDD pacing mode was $186.9 \pm 52.9 \mathrm{~ms}$. The results are summarized in Table 3. As expected, the mean optimal AV delay was lower in the VDD than in the DDD mode. 
Table 3: AVD $_{\text {OPT }}$ VDD = optimal AV delay for atrially triggered (VDD) and atrially paced (DDD) modes

\begin{tabular}{ccc}
\hline patient & AVD $_{\text {OPT }}$ VDD & AVD $_{\text {OPT }}$ DDD \\
\hline 1 & 60 & 172 \\
2 & 78 & 154 \\
3 & 96 & 204 \\
4 & 92 & 132 \\
5 & 92 & 144 \\
6 & 122 & 174 \\
7 & 136 & 216 \\
8 & 64 & 128 \\
9 & 84 & 180 \\
10 & 168 & 252 \\
11 & 168 & 300 \\
& $105,5 \pm 38,1 \mathrm{~ms}$ & $186,9 \pm 52,9 \mathrm{~ms}$ \\
\hline
\end{tabular}

$\mathrm{ARB}=$ Angiotensin-receptor blockers; $\mathrm{CS}=$ coronary sinus

Echocardiography was performed subsequently under three pacemaker settings: $\mathrm{AVD}_{\mathrm{OPT}}, \mathrm{AVD}_{\mathrm{OPT}^{-}}-50$, $\mathrm{AVD}_{\mathrm{OPT}}+50$. All patients had continuous biventricular stimulation even under $\mathrm{AVD}_{\mathrm{OPT}}+50$.

\section{D and TDI echocardiography}

The LVEF with $\mathrm{AVD}_{\mathrm{OPT}}$ was $28 \%( \pm 12 \%)$, with an $\mathrm{AVD}_{\mathrm{OPT}^{-}}-5020 \%\left( \pm 7 \%, \mathrm{p}=0.03\right.$ compared to $\left.\mathrm{AVD}_{\mathrm{OPT}}\right)$, with an $\mathrm{AVD}_{\mathrm{OPT}}+5023 \%( \pm 7 \%, \mathrm{p}=0.11$ compared to $\left.\mathrm{AVD}_{\mathrm{OPT}}\right)$. The heart rate did not change significantly in the different settings $\left(\mathrm{AVD}_{\mathrm{OPT}}\right.$ : 65,4/min, $\mathrm{AVD}_{\mathrm{OPT}_{\mathrm{T}}}-50: 65,6 /$ min, $\mathrm{AVD}_{\mathrm{OPT}^{+}}+50: 65,8 \mathrm{~ms}$ ). The hemodynamics (SVI, CI, LVEF) and the TDI derived data are listed in Table 4. There was no significant difference of the amount of segments with dyssynchrony in TSI in the three settings. The maxi- mal delay in the basal segments in the apical two-, threeand four-chamber views measured by TSI and strain did not differ in the $\mathrm{AVD}_{\mathrm{OPT}}, \mathrm{AVD}_{\mathrm{OPT}^{+}}+50$ and $\mathrm{AVD}_{\mathrm{OPT}}-50$ setting.

\section{Discussion Optimal AV delay}

To date, Ismer's method for the optimal AV delay was applied to patients with DDD pacemakers and normal left ventricular function $[22,23]$. This is the first study to assess the optimal AV delay by Ismer's method in patients with reduced left ventricular function. In our CRT patients, an optimal AV delay according to Ismer's method could be defined. This is the only method that allows separate measurement of the three AV-delay components: i.e., the pacemaker-related interatrial conduction time, the left-atrial electromechanical action, and the leftventricular latency period. The benefits of this method, however, are offset by the necessity for placement of an oesophageal electrode. This requirement explains why only a few medical centres have applied this method in clinical practice and in most cases for purposes of scientific investigation only.

Our results concerning the $\mathrm{AVD}_{\mathrm{OPT}}$ in the VDD mode $(105.5 \pm 38.1 \mathrm{~ms})$ are in agreement with the results of other studies on $\mathrm{AVD}_{\mathrm{OPT}}$ in CRT patients: Butter [16] determined an $\mathrm{AVD}_{\mathrm{OPT}}$ of $100 \mathrm{~ms}$ in 30 patients, Auricchio [17] an $\mathrm{AVD}_{\mathrm{OPT}}$ of $112 \pm 33 \mathrm{~ms}$ in 41 patients and Kass [18] an $\mathrm{AVD}_{\mathrm{OPT}}$ of $125 \pm 49 \mathrm{~ms}$. A study that was recently published by Porciani [29] found an $\mathrm{AVD}_{\mathrm{OPT}}$ during simultaneous biventricular pacing of $97+27 \mathrm{~ms}$.

In the literature, there are no published data on $\mathrm{AVD}_{\mathrm{OPT}}$ in DDD mode. Therefore, our $\mathrm{AVD}_{\mathrm{OPT}}$ in DDD mode of $186.9 \pm 52.9 \mathrm{~ms}$ cannot be compared to other studies.

Table 4: Hemodynamic and Tissue Doppler Echocardiography parameters in the AVD ${ }_{\mathrm{OPT}}, \mathrm{AVD}_{\mathrm{OPT}}-50$ and $\mathrm{AVD}_{\mathrm{OPT}}+50$ modes.

\begin{tabular}{|c|c|c|c|c|}
\hline \multicolumn{5}{|c|}{ Hemodynamics } \\
\hline $\mathrm{SV}[\mathrm{ml}]$ & $\begin{array}{c}\text { AVD }_{\text {OPT }} \\
89,2( \pm 27.7)\end{array}$ & $\begin{array}{l}\mathrm{AVD}_{\mathrm{OPT}}-50 \\
89,7( \pm 36.9)\end{array}$ & $\begin{array}{l}\mathrm{AVD}_{\mathrm{OPT}}+50 \\
95,3( \pm 36.9)\end{array}$ & $\begin{array}{c}P \\
\text { n.s. }\end{array}$ \\
\hline LVEF & $0,28( \pm 0.12)$ & $0,20( \pm 0.07)^{*}$ & $0,23( \pm 0.07)^{* *}$ & $* 0.03 / * * 0.11$ \\
\hline $\mathrm{Cl}$ & $3,0( \pm 0.9)$ & $3,2( \pm 0.8)$ & $3,4( \pm 0.9)$ & n.s. \\
\hline $\mathrm{HR}$ & $65,4( \pm 8.8)$ & $65,6( \pm 9.4)$ & $65,8( \pm 9.4)$ & n.s. \\
\hline \multicolumn{5}{|c|}{ Tissue Doppler } \\
\hline TDI max. delay in basal segments [ms] & $\begin{array}{c}\text { AVD }_{\text {OPT }} \\
122.9( \pm 95,6)\end{array}$ & $\begin{array}{c}\text { AVD }_{\mathrm{OPT}-50} \\
125,0( \pm 109,2)\end{array}$ & $\begin{array}{l}\text { AVD }_{\mathrm{OPT}}+50 \\
|3|, 7( \pm 85,2)\end{array}$ & $\begin{array}{c}P \\
\text { n.s. }\end{array}$ \\
\hline TSI segments with asynchrony & $2,08( \pm 1,24)$ & $2,27( \pm 1.19)$ & $2,41( \pm 1.43)$ & n.s. \\
\hline Strain max. delay in basal segments [ms] & $148,3( \pm 74.9)$ & $167,5( \pm 90.2)$ & $15 \mid, 7( \pm 54.1)$ & n.s. \\
\hline \multicolumn{5}{|l|}{ Strain [\%] } \\
\hline $4 \mathrm{AC}$ lateral & $13,7( \pm 6,5)$ & $14.5( \pm 9.8)$ & $13,4( \pm 9.8)$ & n.s. \\
\hline 4 AC septal & $15,6( \pm 7,3)$ & $13.9( \pm 9.3)$ & $15.0( \pm 9.8)$ & n.s. \\
\hline $\mathrm{A} 2 \mathrm{C}$ anterior & $16,8( \pm 9,7)$ & $17.2( \pm 10.5)$ & $16.1( \pm 9.1)$ & n.s. \\
\hline $\mathrm{A} 2 \mathrm{C}$ inferior & $20,0( \pm 11,5)$ & $15.0( \pm 11.4)$ & $16.1( \pm 9.8)$ & n.s. \\
\hline $\mathrm{A} 3 \mathrm{C}$ anterior & $19,7( \pm 9,5)$ & $12.4( \pm 9.7)$ & $18.1( \pm 9.8)$ & n.s. \\
\hline $\mathrm{A} 3 \mathrm{C}$ interior & $19,1( \pm 9,8)$ & $14.1( \pm 12.7)$ & $19.2( \pm 10.1)$ & n.s. \\
\hline
\end{tabular}




\section{Hemodynamics}

Intra-individually, the patients had the best LVEF under optimal AV-delay compared to the +50 and -50 ms settings. The LVEF is significantly higher in the $\mathrm{AVD}_{\mathrm{OPT}}$ setting than in the $\mathrm{AVD}_{\mathrm{OPT}}-50$ setting. Obviously the formation of "cannon waves" seen with a shorter AV interval $\left(\mathrm{AVD}_{\mathrm{OPT}}-50\right)$ had a more negative hemodynamic effect than the diastolic mitral regurgitation seen with longer AV delays $\left(\mathrm{AVD}_{\mathrm{OPT}}+50\right)$. The hemodynamically unfavourable effects of "cannon waves" are described since the beginning of pacemaker therapy and are also termed "pacemaker syndrome". It is generally accepted that an adequate pacemaker programming can avoid this [30]. Toda et al. [31] could show in his studies that the mean LVEF in $A D_{\mathrm{OPT}}$ is higher than in prolonged $A V$ delays. However, he found no significant difference.

\section{Dyssynchrony}

Changes of dyssynchrony can be seen immediately, as seen in studies that have examined on/off comparisons in CRT patients [32]. However, an optimized AV interval does not change the markers of dyssynchrony. The reason for the improved hemodynamic situation under $\mathrm{AVD}_{\mathrm{OPT}}$ seems to be the better left ventricular filling and not the altered dyssynchrony.

\section{Limitations}

This study included only a small number of patients. There was no follow-up examination of the patients.

\section{Conclusion}

This study confirmed that an optimized AV delay improves the left ventricular ejection fraction. Acutely, the optimized AV delay does not influence left ventricular dyssynchrony. Whether a long-term $\mathrm{AVD}_{\mathrm{OPT}}$ leads to changes in left ventricular dyssynchrony via an improved LVEF and reverse remodelling can only be speculated. This has to be addressed in future studies with a long-term observation interval.

$$
\begin{aligned}
& \text { Abbreviations } \\
& \mathrm{AVD}_{\mathrm{OPT}} \text { optimal AV delay } \\
& \mathrm{AVD}_{\mathrm{OPT}^{-}} 50 \text { optimal AV delay }-50 \mathrm{~ms} \\
& \mathrm{AVD}_{\mathrm{OPT}}+50 \text { optimal AV delay }+50 \mathrm{~ms}
\end{aligned}
$$

CRT Cardiac Resynchronization Therapy

DCM Dilated Cardiomyopathy

EMD Electromechanical Delay

IVMD Inter-ventricular mechanical delay
LBBB Left Bundle Branch Block

SRI strain rate imaging

TDI Tissue Doppler Imaging

TSI Tissue Synchronization Imaging

VDD atrially triggered mode

DDD atrailly paced mode

EAC the end of the A-wave

LVEF Left ventricular ejection fraction

\section{Competing interests}

The author(s) declare that they have no competing interests.

\section{Authors' contributions}

$\mathrm{CM}$ and FK have equally contributed to this publication. $\mathrm{CM}, \mathrm{BI}, \mathrm{FK}$ and $\mathrm{ACB}$ have designed and performed the study and have written the manuscript. HJB, CAN and GB have participated in the study design and coordination and have helped to draft the manuscript. All authors read and approved the final manuscript.

\section{References}

I. Bristow MR, Saxon LA, Boehmer J, Krueger S, Kass DA, De Marco T, Carson P, DiCarlo L, DeMets D, White BG, DeVries DW, Feldman AM, Comparison of Medical Therapy Pacing and Defibrillation in Heart Failure (COMPANION) Investigators: Cardiac Resynchronization Therapy with or without an Implantable Defibrillator in Advanced Chronic Heart Failure. N Eng J Med 2004, 350:21 40-2I50.

2. Linde C, Leclercq C, Rex S, Garrigue S, Lavergne T, Cazeau S, McKenna W, Fitzgerald M, Deharo JC, Alonso C, Walker S, Braunschweig F, Bailleul C, Daubert JC: Long-term benefits of biventricular pacing in congestive heart failure: results from the MUltisite STimulation in cardiomyopathy (MUSTIC) study. J Am Coll Cardiol 2002, 40:111-118.

3. Abraham WT, Fisher WG, Smith AL, Delurgio DB, Leon AR, Loh E, Kocovic DZ, Packer M, Clavell AL, Hayes DL, Ellestad M, Trupp RJ, Underwood J, Pickering F, Truex C, cAtee P, Messenger J, MIRACLE Study Group: Multicenter InSync Randomized Clinical evaluation. Cardiac resynchronization in chronic heart failure. $N$ Engl J Med 2002, 346: | 845-1853.

4. Cazeau S, Leclercq C, Lavergne T, Walker S, Varma C, Linde C, Garrigue S, Kappenberger L, Haywood GA, Santini M, Bailleul C, Daubert JC, Multisite Stimulation in Cardiomyopathies (MUSTIC) Study Investigators: Effects of multisite biventricualr pacing in patients with heart failure and intraventricular conduction delay. $N$ Engl J Med 200 I, 344:873-880.

5. Saxon LA, De Marco T, Schafer J, Chatterjee K, Kumar UN, Foster E: VIGOR Congestive Heart Failure Investigators. Effects of long-term biventricular stimulation for resynchronization on echocardiographic measures of remodeling. Circulatio 2002, 105:1304-1310.

6. Sundell J, Engblom E, Koistinen J, Ylitalo A, Naum A, Stolen KQ, Kalliokoski R, Nekolla SG, Airaksinen KE, Bax J], Knuuti J: The effects of cardiac resynchronization therapy on left ventricular function, myocardial energetics, and metabolic reserve in patients with dilated cardiomyopathy and heart failure. J Am Coll Cardiol 2004, 43(6): 1027-1033. 
7. Cleland JG, Daubert JC, Erdmann E, Freemantle N, Gras D, Kappenberger L, Tavazzi L, Cardiac Resynchronization-Heart Failure (CAREHF) Study Investigators: The effect of cardiac resynchronization on morbidity and mortality in heart failure. N EnglJ Med 2005, 352(I5): 1539-1549.

8. Eugene M, Lascault G, Frank R, Fontaine G, Grosgogeat Y, Teillac A: Assessment of the optimal atrio-ventricular delay in DDD paced patients by impedance plethysmography. Eur Heart $J$ 1989, 10:250-255.

9. Kindermann M, Fröhlig G, Doerr T, Schieffer H: Optimizing the AV delay in DDD pacemaker patients with high degree AV block: mitral valve doppler versus impedance cardiography. PACE 1997, 20:2453-2462.

10. Ovsyshcher IE: Toward physiological pacing: optimization of cardiac hemodynamics by AV delay adjustment. PACE 1997, 20:86I-865.

II. Ishikawa T, Sumita S, Kimura K, Kikuchi M, Kosuge M, Kuji N, Endo T, Sugano T, Sigemasa T, Kobayaski I, Tochikubo I, Usui T: Prediction of optimal atrioventricular delay in patients with implanted DDD pacemakers. PACE 1999, 22:1365-I37|.

12. Von Knorre GH, Petzsch M, Ismer B: Approximation of optimal atrioventricular delay in DDD pacemaker patients with atrioventricular block by oesophageal electrocardiography (abstract). Eur Heart J 1996, I7(Supplement):487.

13. Ritter Ph, Dib JC, Lelievre T: Quick determination of the optimal AV delay at rest in patients paced in DDD mode for complete AV block. (abstract). Eur J CPE 1994, 4(2):AI63.

14. Ritter P, Padeletti L, Gillio-Meina L, Gaggini G: Determination of the optimal atrioventricular delay in DDD pacing. Comparison between echo and peak endocardial acceleration measurements. Europace 1999, I:126-30.

15. Occhetta E, Rognoni G, Perucca A, Aina F, Magnani A, Francalacci G, Rossi P: The functional and hemodynamic benefits of automatic atrioventricular interval delay in permanent atrial synchronized pacing. G Ital Cardiol 1993, 23:877-886.

16. Butter C, Auricchio A, Stellbrink C, Fleck E, Ding J, Yu Y, Huvelle E, Spinelli J, Pacing Therapy for Chronic Heart Failure II Study: Effect of resynchronization therapy stimulation site on the systolic function of heart failure patients. Circulation 200I, 104:3026-3029.

17. Auricchio A, Stellbrink C, Sack S, Block M, Vogt J, Bakker P, Huth C, Schondube F, Wolfhard U, Bocker D, Krahnefeld O, Kirkels H, Pacing Therapies in Congestive Heart Failure (PATH-CHF) Study Group: Long-term clinical effect of hemodynamically optimized cardiac resynchronization therapy in patients with heart failure and ventricular conduction delay. J Am Coll Cardiol 2002, 39:2026-2033.

18. Kass D, Chen CH, Curry C, Talbot M, Berger R, Fetics B, Nevo E: Improved left ventricular mechanics from acute VDD pacing in patients with dilated cardiomyopathy and ventricular conduction delay. Circulation 1999, 99:1567-1573.

19. Auricchio A, Stellbrink C, Block M, Sacks S, Vogt J, Bakker P, Klein H, Kramer A, Ding J, Salo R, Tockmann B, Pochet T, Spinelli J: Effect of pacing chamber and atrioventricular delay on acute systolic function of paced patients with congestive heart failure. Circulation 1999, 99:2993-300I.

20. Stellbrink C, Breithardt OA, Diem B, Franke A, Pochet T, Salo R, Auricchio A: Acute effects of multisite pacing with different AV delays on diastolic and systolic function in congestive heart failure (abstract). PACE 1999, 22:829.

21. Meluzin J, Novak M, Mullerova J, Krejci J, Hude P, Eisenberger M, Dusek L, Dvorak I, Spinarova L: A fast and simple echocardiographic method of determination of the optimal atrioventricular delay in patients after biventricular stimulation. Pacing Clin Electrophysiol 2004, 27:8-64.

22. Ismer B, von Knorre GH, Voß W, Körber T: Definition of the optimal atrioventricular delay by simultaneous measurement of electrocardiographic and doppler-echocardiographic parameters. Prog Biomed Res 2003, 7: II I6- 120

23. Ismer B, von Knorre G, Voss W, Grille W, Klenke G, Kamesh Pulya, Koglek W, Suntinger A, Luessow H: Exercise induced sympathetic influences do not change interatrial conduction times in VDD and DDD pacing. PACE 1996, 19:1786-1790.

24. Borges AC, Kivelitz D, Walde T, Reibis RK, Grohmann A, Panda A, Wernecke KD, Rutsch W, Hamm B, Baumann G: Apical tissue tracking echocardiography for characterization of regional left ventricular function: comparison with magnetic resonance imaging in patients after myocardial infarction. J Am Soc Echocardiogr 2003, 3:254-262.

25. Mele D, Pasanisi G, Heimdal A, Cittanti C, Guardigli G, Levine RA Sutherland G, Ferrari R: Improved recognition of dysfunctioning myocardial segments by longitudinal strain rate versus velocity in patients with myocardial infarction. J Am Soc Echocardiogr 2004, 4:3 I3-32I.

26. Gorcsan J, Kanzaki H, Bazaz R, Dohi K, Schwartzman D: Usefulness of Echocardiografic Tissue Synchronization Imaging to Predict Acute Response to Cardiac Resynchronization Therapy. Am I Cardiol 2004, 93: I 178-1 I8I.

27. Yu CM, Zhang Q, Fung JW, Chan HC, Chan YS, Yip GW, Kong SL, Lin $H$, Zhang $Y$, Sanderson JE: A novel tool to assess systolic asynchrony and identify responders of cardiac resynchronization therapy by tissue synchronization imaging. J Am Coll Cardiol 2005, 45(5):677-684.

28. Knebel F, Reibis RK, Bondke HJ, Witte J, Walde T, Eddicks S, Baumann G, Borges AC: Tissue Doppler echocardiography and biventricular pacing in heart failure: patient selection, procedural guidance, follow-up, quantification of success. Cardiovasc Ultrasound 2004, 2(I): 17.

29. Porciani MC, Dondina C, Macioce R, Demarchi G, Pieragnoli P, Musilli N, Colella A, Ricciardi G, Michelucci A, Padeletti L: Echocardiographic examination of atrioventricular and interventricular delay optimization in cardiac resynchronization therapy. Am J Cardiol 2005, 95: I I08- I I I0.

30. Schuller $\mathrm{H}$, Brandt J: The pacemaker syndrome: old and new causes. Clin Cardiol I99I, 14:336-340.

3I. Toda N, Ishikawa T, Nozawa N, Kobayashi I, Oghial H, Miyamoto K, Sumita S, Kimura K, Umemura S: Doppler index and plasma level of atrial natriuretic hormone are improved by optimizing atrioventricular delay in atrioventricular block patients with implanted DDD pacemakers. PACE 200I, 24:1660-1663.

32. Breithardt OA, Sinha AM, Schwammenthal E, Bidaoui N, Markus KU, Franke A, Stellbrink C: Acute effects of cardiac resynchronization therapy on functional mitral regurgitation in advanced systolic heart failure. J Am Coll Cardiol 2003, 4 I (5):765-770.
Publish with BioMed Central and every scientist can read your work free of charge

"BioMed Central will be the most significant development for disseminating the results of biomedical research in our lifetime. "

Sir Paul Nurse, Cancer Research UK

Your research papers will be:

- available free of charge to the entire biomedical community

- peer reviewed and published immediately upon acceptance

- cited in PubMed and archived on PubMed Central

- yours - you keep the copyright
BioMedcentral 